\title{
Studies on the spatial variability of rebound hammer test results recorded at in-situ testing
}

\author{
AdorJÁN BOROSNYÓ| - Assoc. Prof., BME, Dept. of Construction Materials and Engineering Geology " \\ adorjan.borosnyoi@gmail.com \\ KATALIN SZILÁGYI - PhD candidate, BME, Dept. of Construction Materials and Engineering Geology * \\ szilagyikt@gmail.com \\ Received: 14. 11. 2013. - Érkezett: 2013. 11. 14. - http://dx.doi.org/10.14382/epitoanyag-jsbcm.2013.19
}

\section{Abstract}

Variability of the in-situ rebound hammer tests is composed of the inherent variability of the measuring method and the spatial variability of the concrete performance properties. In-situ, Schmidt rebound hammer tests were performed at the bottom surface of a concrete slab, with dimensions of $25.0 \mathrm{~m} \times 7.5 \mathrm{~m}$. The studied region on was $22.0 \mathrm{~m} \times 6.0 \mathrm{~m}$. The analysis of the inherent variability of the rebound hammer tests was limited to the comparison of the statistical location parameters; mean, median and mode values. The spatial variability was analysed by contour plots and semivariograms of the statistical location parameters. It was demonstrated that the geostatistical methods may be applicable for the much smaller scale concrete structures than the scale of geological formations. Semivariograms and semivariogram models seem to be useful tools for the characterisation of spatial variability of concrete structures.

Keywords: concrete, rebound hardness, Schmidt hammer, spatial variability, statistical location parameters, semivariogram

\section{Introduction}

The magnitude of the variation in the strength of structural concrete is a result of the level of quality control over the concrete production, transportation, compacting and curing procedures. The compressive strength of the concrete is not measured in the structure during in-situ non-destructive testing (NDT), but some other property is measured instead that is correlated to the compressive strength. The strength of concrete is estimated from a previously established relationship between the measured NDT property and the compressive strength. The uncertainty of the estimated compressive strength, therefore, depends both on the variability of the in-situ measurements and the uncertainty of the relationship between the measured NDT property and compressive strength. Variability of the in-situ measurements is composed of the inherent variability of the measuring method (repeatability and reproducibility; attributed to the operation mode and the calibration conditions of the testing device, to the operator and to environmental influences) and the spatial variability of the concrete performance properties due to differences of compaction and curing, possible non-uniform supply of material and structural effects (reinforcement, changes in dimension, corners, connecting structural elements etc.). Inherent variability phenomena can be considered as point properties (local parameter). Spatial variability phenomena can be considered as regional properties (regional or volume parameter). Local phenomena can be analysed by classical statistical methods. Analysis of regional phenomena needs spatial models - that are typically used in geostatistics.

Development of geostatistical tools is attributed to Prof. George Matheron who published his treatise on the Theory of Regionalised Variables and its Applications based on earlier empirical work in the 1960s [1], nevertheless, the basic idea of kriging (Gaussian piecewise-polynomial spline interpolation regression) is first used in a technical context by Prof. Danie G. Krige, in his study about average gold grades at the Witwatersrand reef complex in South Africa [2]. Historically, Prof. Andrey N. Kolmogorov was the first who recognized spatial correlation. He defined the so-called structure function for its representation and developed how to use the structure function for optimal interpolation (without bias and with minimum variance) [3]. Kolmogorov was unable to use the method due to the lack of computer power in those days [4]. Kolmogorov's structure function is known today as the variogram and his interpolation technique as kriging.

Geostatistics deals with spatially autocorrelated data (autocorrelation $=$ correlation between elements of a series and others from the same series separated from them by a given interval). Some spatially autocorrelated parameters of interest in geostatistics are facies, reservoir thickness, porosity, permeability [5].

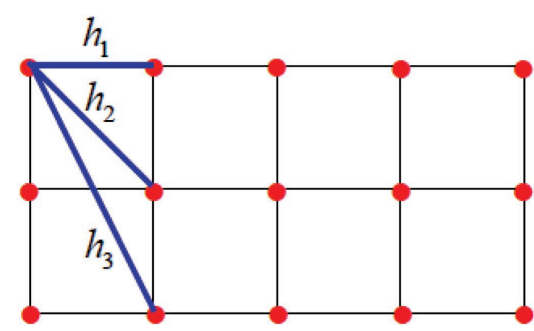

Fig. 1. Schematic representation of lag vectors in 2D [7]

1. ábra Kétdimenziós helyvektorok sematikus megjelenitése [7]

Geostatistics usually assumes that the differences between the values of samples are determined by the relative spatial orientation of the samples and the mean and variance of 
the differences depend only on the relative orientation [6]. Therefore, the semivariogram is introduced in spatial correlation analyses that plots the semivariance of samples as the function of the separation between two spatial locations (referred to as lag).

For the development of the semivariogram, let us suppose a $2 \mathrm{D}$ field of values of a variable $f(\mathrm{x}, \mathrm{y})$ as indicated in Fig. 1. Lags are schematically shown as $h_{1}, h_{2}$ and $h_{3}$.

For the determination of a semivariogram corresponding to a $2 \mathrm{D}$ field of values of a variable $f(\mathrm{x}, \mathrm{y})$, the followings can be considered:

u vector of spatial coordinates (with 2D components $x$ and $y)$

$f(\mathbf{u})$ variable under consideration as a function of spatial location,

h lag vector representing separation between two spatial locations,

$f(\mathbf{u}+\mathbf{h})$ lagged version of variable under consideration, $N(\mathbf{h})$ the number of data pairs separated by lag $\mathbf{h}$.

Semivariance $\gamma(\mathbf{h})$ can be determined for lag $\mathbf{h}$ as of Eq. (1):

$\gamma(\mathbf{h})=\frac{1}{2 N(\mathbf{h})} \sum_{i=1}^{N(\mathbf{h})}\left[f\left(\mathbf{u}_{i}+\mathbf{h}\right)-f\left(\mathbf{u}_{i}\right)\right]^{2}$

Semivariance is a measure of the dissimilarity of the values. The empirical function of $\gamma(\mathbf{h})$ can be considered as a population parameter. The diagram showing the semivariance versus lag is referred to as the semivariogram.

Geostatistical analyses prefer using the semivariogram since the semivariogram tends to filter the influence of a spatially varying mean by averaging the squared differences of the variable. Also, the semivariogram can be applied whenever the covariance function cannot be defined. In such a case the semivariance may keep increasing with increasing lag, rather than leveling off, corresponding to an infinite global variance; and the covariance function is undefined [5].

\section{Spatial variability analysis for in-situ rebound hammer testing}

Typical relative strength variation for structural concrete in a wall is illustrated in Fig. 2 [8]. The strength gradients are reasonably uniform due to gravity and the variations in compaction and supply is visible in the variability indicated by the relative strength contours. Anisotropy is always realised in the compressive strength of structural members in vertical direction (including columns, walls, beams and thick slabs).

Considering the bottom surface of a slab, the variability of the compressive strength in horizontal direction is expected to be random due to only compaction and supply inconsistencies. The study of the spatial variability of concrete performance properties is, therefore, reasonable to be carried out for a bottom surface of a slab where the vertical bias in the compressive strength is excluded and the clear random influences due to only compaction and supply differences can be analysed.

For such an analysis, the bottom surface of the top concrete slab of a framed, monolithic, subsoil concrete tunnel was selected, with dimensions of $25.0 \mathrm{~m} \times 7.5 \mathrm{~m}$ with a thickness of $0.48 \mathrm{~m}$. The studied region on the bottom surface was $22.0 \mathrm{~m}$ $\times 6.0 \mathrm{~m}$.

A total number of 42 testing locations were selected for Schmidt rebound hammer testing. N-type original Schmidt rebound hammer was used. Eleven individual rebound index readings were recorded at each location. The measurements were performed by the same operator.

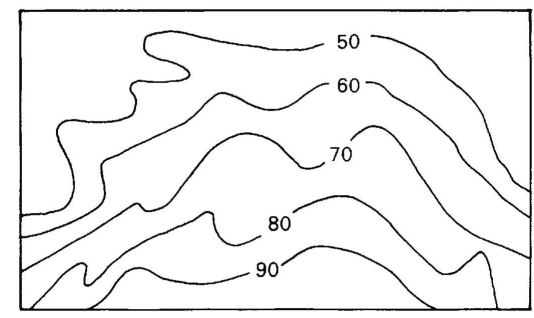

Fig. 2. Relative strength variation for a structural concrete wall [8] 2. ábra Relatív nyomószilárdság változása beton falban [8]

\section{Results}

The present paper discusses the spatial variability of the measured rebound indices $\left(\mathrm{R}_{\mathrm{i}}\right)$ based exclusively on the statistical location parameters, i.e. test location mean $-E[\mathrm{R}]$ values, test location median $-m[\mathrm{R}]$ values and test location mode $-M o[\mathrm{R}]$ values.

A total number of 462 individual rebound indices were recorded at the 42 testing locations. The frequency histogram of the individual rebound indices without any separation by location is indicated in Fig. 3 together with the best fit probability density function.

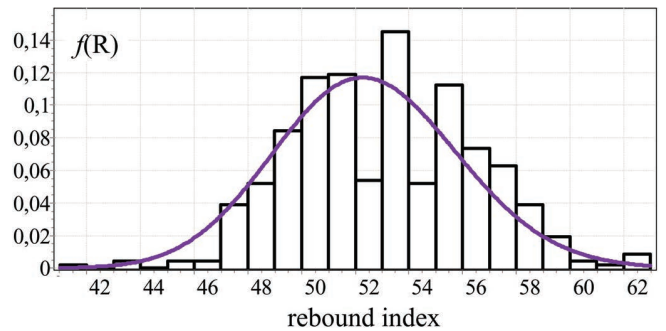

Fig. 3. Frequency histogram of the individual rebound indices for the 42 testing locations without any separation by location

3. ábra A 42 mérési helyen rögzitett visszapattanási értékek együttes relatív gyakorisági hisztogramja

Considering the rebound hammer test, it can be assumed that the rebound index reading sets of separate testing locations are independent and identically distributed (i.i.d.) random variables since it can be supposed that the probability distribution of the rebound index does not change by location within the same concrete structure and the separate testing locations can be considered to be mutually independent [9]. Based on these assumptions, the central limit theorem applies for the rebound hammer test; i.e. the probability distribution of the mean of the rebound index reading sets of separate testing locations (each with finite mean and finite variance) approaches the normal distribution if sufficiently large number of the i.i.d. random variables is available. It can be realised that the mean of the 42 independent testing locations approaches rather well to the normal distribution. 

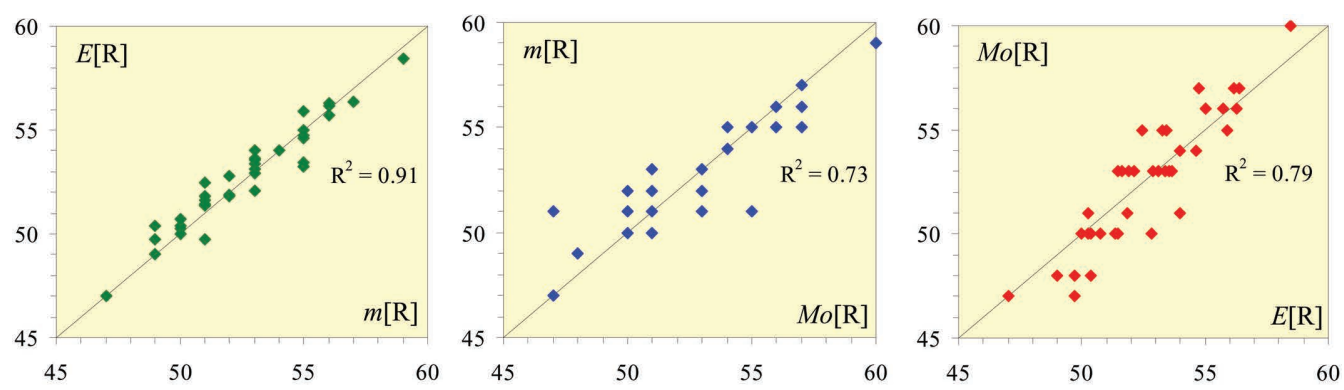

Fig. 4. Correlations between the mean, median and mode values for the 42 testing locations

4. ábra A visszapattanási értékek 42 mérési helyre vonatkozó átlagának, mediánjának és móduszának korrelációi
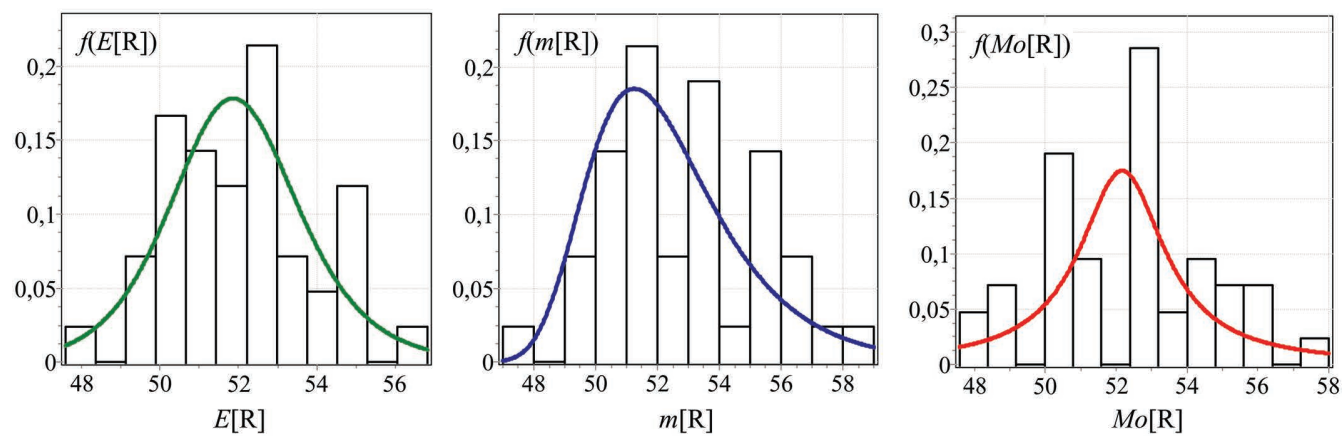

Fig. 5. Frequency histograms for the mean, median and mode values for the 42 testing locations

5. ábra A visszapattanási értékek 42 mérési helyre vonatkozó átlagának, mediánjának és móduszának gyakorisági hisztogramjai

For the 462 individual rebound indices, the global mean value is $E[R]=52.6$, the global median value is $m[R]=53$ and the global mode value is $M o[R]=53$. Fig. 4 illustrates the rather close correlations between the statistical location parameters corresponding to the 42 testing locations.

Fig. 5 indicates the frequency histograms of the statistical location parameters; mean $-E[R]$ values, median $-m[R]$ values and mode $-M o[R]$ values, respectively. Findings confirm that the three location parameters are not equally sensitive to the extreme individual values of which possible influences seem to rule out for the mean values (frequency histogram and best fit probability density function have almost zero skewness or excess kurtosis), on the contrary to the median values (where frequency histogram and best fit probability density function show positive skewness) and the mode values (where frequency histogram and best fit probability density function show positive excess kurtosis).

In a practical situation, when noticing or localising of the presence of eventually weaker regions of the structural element can be one purpose, the analysis of mean responses may be misleading; in the case of sufficiently large number of testing locations the central limit theorem applies and global observations can hide the influence of local extremities.

Contour plots may indicate local information in a visible way. Maps of the statistical location parameters for mean $E[\mathrm{R}]$ values, median $-m[\mathrm{R}]$ values and mode $-M o[\mathrm{R}]$ values are shown in Fig. 6, respectively. It can be seen that the three parameters broadly show similar differences in the measured values, however, the extremities are observable the best at the contour plot of the mode values. Contour plot of the mean values seems to be the least sensitive in this sense. It can be also noted that different performance areas can be observed on particular maps that are not visible on the other two maps. Results evidently show the influences due to compaction and supply differences. The observed behaviour can be considered, however, result of random influences. No clear tendencies in the differences of the performance properties are realised.

In a practical situation, when eventually weaker regions of the structural element are present, it can be interesting to know that at which extent and in which orientation the discrepancy is present and has influence on performance properties. Geostatistical approaches can be used for the analysis of spatial variation. The method of kriging is applicable for modelling Gaussian random processes, based on models of semivariograms for a variable $[1,4,6]$. Semivariograms may indicate the lag distance (=range) over which the values of the variable are not correlated (independent). This distance can be referred to as correlation distance. The sill is the semivariance value at which the semivariogram levels off. The nugget is the semivariance value at distances smaller than the minimum lag of measurements $[4,6]$. Typical models for semivariograms are the spherical, exponential, Gaussian, wave, nugget [4-7]. Combined models are also used.

Fig. 7 represents the empirical semivariograms for the statistical location parameters; mean - $\gamma(E[\mathrm{R}])$, median $\gamma(m[\mathrm{R}])$ and mode $-\gamma(M o[\mathrm{R}])$, respectively. The best fit spherical models are also indicated. It can be realised that the semivariogram models level off at a range about ten meters. In geostatistics, a common rule of thumb is accepted for the maximum lag in a semivariogram restricted to half of the diagonal of data extent [10]. In the present example, the concrete slab has dimensions of $25.0 \mathrm{~m} \times 7.5 \mathrm{~m}$ of which the studied region is $22.0 \mathrm{~m} \times 6.0 \mathrm{~m}$. Semivariograms in Fig. 7 are, however, not limited to about 12 meters since one dimension 

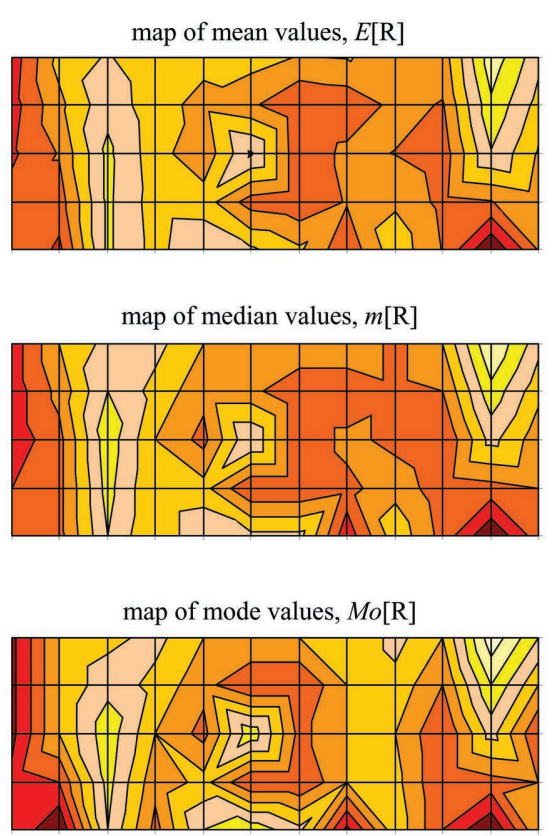

Fig. 6. Contour plots for the mean, median and mode values over the tested area

6. ábra A visszapattanási értékek átlagának, mediánjának és móduszának szintvonalas ábrázolása
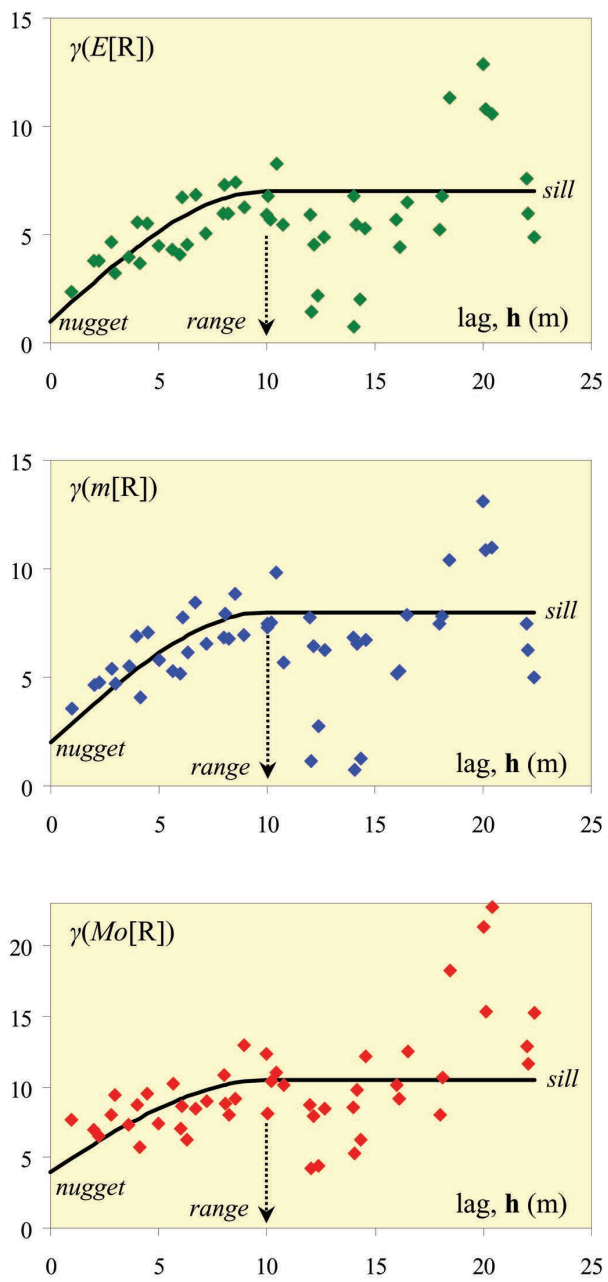

Fig. 7. Semivariograms for the mean, median and mode values for the 42 testing locations together with the best fit spherical model

7. ábra A visszapattanási értékek 42 mérési helyre vonatkozó átlagának, mediánjának és móduszának félvariogramjai, szférikus modellel közelitve of the slab is three times larger than the other. Restricting the semivariograms at maximum lag about half of the diagonal of data extent would not allow the diagrams to visibly level off and the sill could not be clearly determined. It can be realised that the spatial variability of the mean and median values is of the same magnitude, and the spatial variability of the mode values is a little higher. It can be concluded that the testing locations can provide uncorrelated (independent) results for the rebound index readings over a lag distance of about ten meters.

\section{Conclusions and future work}

The present paper has summarised the application possibilities of particular geostatistical tools for modelling the spatial variability of rebound hammer non-destructive testing. Results of in-situ measurements were provided and analysed. The analysis of the inherent variability of the rebound hammer tests was limited to the comparison of the statistical location parameters; mean $-E[R]$ values, median $-m[R]$ values and mode $-M o[R]$ values. It was demonstrated that the statistical location parameters signify the inherent variability by different sensitivities. The spatial variability was analysed by contour plots and semivariograms of the statistical location parameters. It was demonstrated that the geostatistical methods may be applicable for the much smaller scale concrete structures than the scale of geological formations. Semivariograms and semivariogram models seem to be useful tools for the characterisation of spatial variability of concrete structures.

The spatial variability of geological and hydrological variables is well-described in the geostatistical literature for a long time. The use of the geostatistical methods for concrete structures is, however, still very much limited today. Further research is needed about the probability distribution of NDT measures and their influence on the boundary conditions for geostatistical methods. Size effect studies are also needed since the correlation distances are expected to be considerably different in particular cases - changing in the range of ten centimetres to ten meters -, depending on the actual workmanship and material supply. It is also of interest, which statistical parameter of the recorded NDT measure is the most suitable for a useful spatial variability analysis.

\section{Acknowledgements}

This research was supported by the Hungarian Scientific Research Fund project "Durability and performance characteristics of concretes with novel type supplementary materials" (OTKA K 109233) (Adorján Borosnyói) and by the European Union and the State of Hungary, co-financed by the European Social Fund in the framework of TÁMOP 4.2.4. A/1-11-1-2012-0001 'National Excellence Program' (Katalin Szilágyi).

\section{References}

[1] Matheron, G.: The Theory of Regionalised Variables and its Applications. Les Cahiers Du Centre De Morphologie Mathématique de Fontainebleau, No. 5, École Nationale Supérieure des Mines de Paris, 1 January 1971, 211 p.

[2] Krige, D. G.: A statistical approach to some basic mine valuation problems on the Witwatersrand. Journal of the Chemical, Metallurgical and Mining Society of South Africa, Vol. 52, No. 6, December 1951, pp. 119-139. http:// dx.doi.org/10.2307/3006914 
[3] Kolmogorov, A. N.: Interpolation and Extrapolation of Stationary Random Sequences (Интерполирование и экстраполирование стационарных случайных последовательностей). Isvestia AN SSSR, Seriya Matematicheskaya (Известия АН СССР Серия математическая), Vol. 5, No. 1, 1941, pp. 3-14. (in Russian) http://mi.mathnet.ru/izv3775

[4] Webster, R. - Oliver, M. A.: Geostatistics for Environmental Scientists. 2nd Ed., John Wiley \& Sons Ltd, West Sussex, UK, 2007, 315 p. http:// dx.doi.org/10.1002/9780470517277.ch1

[5] Bohling, G.: Introduction to Geostatistics and Variogram Analysis. Lecture notes for Data Analysis in Engineering and Natural Science, Kansas Geological Survey, University of Kansas, 17 October 2005, 20 p. http://people.ku.edu/ gbohling/cpe940/Variograms.pdf

[6] Clark, I.: Practical Geostatistics. Geostokos Ltd, Alloa, UK, 13 July 2001, 120 p. http://www.kriging.com/PG1979/PG1979.pdf

[7] Smith, T. E.: Notebook for Spatial Data Analysis. Lecture notes for Spatial Data Analysis with GIS Applications, University of Pennsylvania, Department of Electrical and Systems Engineering, 2 January 2013, 390 p. http://www.seas.upenn.edu/ ese502/\#notebook

[8] Bungey, J. H. - Millard, J. H. - Grantham, M. G.: Testing of Concrete in Structures. Taylor and Francis, New York, 2006, 352 p.

[9] Szilágyi, K. - Borosnyói, A. - Zsigovics, I.: Extensive statistical analysis of the variability of concrete rebound hardness based on a large database of 60 years experience. Construction and Building Materials, Vol. 53, February 2014, pp. 333-347 http://dx.doi.org/10.1016/j.conbuildmat.2013.11.113

[10] Coombes, J.: Handy Hints For Variography. Snowden Associates Ltd, 2005, 16 p.

$\underline{\text { Ref.: }}$

Adorján Borosnyói - Katalin Szilágyi: Studies on the spatial variability of rebound hammer test results recorded at in-situ testing Építőanyag, 65. évf. 4. szám (2013), 102-106. p. http://dx.doi.org/10.14382/epitoanyag-jsbcm.2013.19
Mérőhelyek közötti változékonyság értékelése Schmidtkalapáccsal végzett helyszíni vizsgálat során

A helyszíni Schmidt kalapácsos vizsgálati eredmények változékonysága két hatásból tevôdik össze: a mérôhelyi változékonyságból (ismételhetôség és reprodukálhatóság) és a mérôhelyek közötti változékonyságból, amely a térben eltérô bedolgozási és utókezelési hatások és az esetlegesen eltérô összetételú beton szállítmány eredménye. A mérőhelyi változékonyság statisztikai paraméterei a klasszikus matematikai statisztika eszközeivel kezelhetốk. A mérôhelyek közötti változékonyság statisztikai paramétereinek vizsgálata térbeli statisztikai modelleket igényel, amelyeket a geostatisztika használ széles körben. A térbeli változékonyság leírására használt modelleket a geostatisztika szakirodalma részletesen, régóta tárgyalja. Ennek ellenére, vasbeton szerkezetek vizsgálatára e módszerek napjainkban még nem terjedtek el. A cikk bemutatja egy $25 \times 7,5 \mathrm{~m}$ méretú vasbeton födém 22×6 m méretũ szakaszának helyszíni schmidt kalapácsos vizsgálati eredményeit. A mérôhelyi változékonyság vizsgálata során bemutatjuk a mérési helyekre meghatározott helyzeti statisztikai jellemzők (számtani közép, medián, módusz) jellegzetességeik és egymáshoz viszonyított kapcsolatukat. Bemutatjuk, hogy a helyzeti statisztikai jellemzốk más-más érzékenységgel jelzik a mérôhelyi változékonyságot. A mérôhelyek közötti változékonyság vizsgálata során bemutatjuk a helyzeti statisztikai jellemzốk térbeli eloszlását és azok félvariogramjait. Bemutatjuk, hogy a geostatisztikában, nagy léptékben alkalmazott térbeli statisztikai modellek alkalmasak vasbeton szerkezetekre történô adaptálásra, kisebb léptékben is. A félvariogramok és azok közelítô modelljei alkalmasak a vasbeton szerkezetek helyszíni, Schmidt kalapácsos vizsgálati eredményeire vonatkozóan a méröhelyek közötti változékonyság vizsgálatára.

Kulcsszavak: beton, felületi keménység, Schmidtkalapács, térbeli változékonyság, statisztikai helyzeti jellemzôk, félvariogram

\section{KÖNYVAJÁNLÓ - BOOK REVIEW}

\section{Francis D. K. Ching BUILDING STRUCTURES ILLUSTRATED}

A new edition of Francis D.K. Ching's illustrated guide to structural design.

Structures are an essential element of the building process, yet one of the most difficult concepts for architects to grasp. While structural engineers do the detailed consulting work for a project, architects should have enough knowledge of structural theory and analysis to design a building. Building Structures Illustrated takes a new approach to structural design, showing how structural systems of a building-such as an integrated assembly of elements with pattern, proportions, and scale-are related to the fundamental aspects of architectural design. The book features a one-stop guide to structural design in practice, a thorough treatment of structural design as part of the entire building process, and an overview of
January 2014 ISBN: 978-1-118-45835-8 352 pages

the historical development of architectural materails and structure. Illustrated throughout with Ching's signature line drawings, this new Second Edition is an ideal guide to structures for designers, builders, and students.

- Updated to include new information on building code compliance, additional learning resources, and a new glossary of terms

- Offers thorough coverage of formal and spatial composition, program fit, coordination with other building systems, code compliance, and much more

- Beautifully illustrated by the renowned Francis D.K. Ching Building Structures Illustrated, Second Edition is the ideal resource for students and professionals who want to make informed decisions on architectural design.

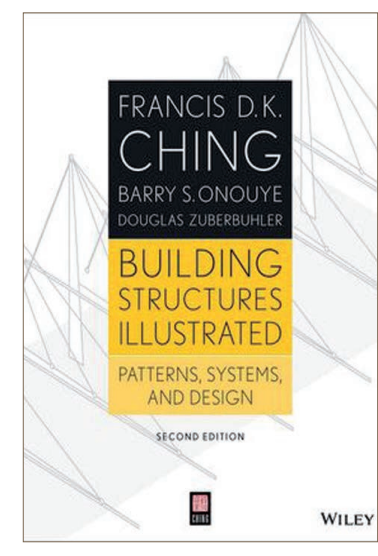

\section{Costas Georgopoulos, Andrew Minson SUSTAINABLE CONCRETE SOLUTIONS}

February 2014, Wiley-Blackwell ISBN: 978-1-119-96864-1

224 pages

The challenges facing humanity in the 21 st century include climate change, population growth, overconsumption of resources, overproduction of waste and increasing energy demands. For construction practitioners, responding to these challenges means creating a built environment that provides accommodation and infrastructure with better whole-life performance using lower volumes of primary materials, less non-renewable energy, wasting less and causing fewer disturbances to the natural environment. Concrete is ubiquitous in the built environment. It is therefore essential that it is used in the most sustainable way so practitioners must become aware of the range of sustainable concrete solutions available for construction. While sustainable development has been embedded into engineering curricula, it can be difficult for students and academics to be fully aware of the innovations in sustainable construction that are developed by the industry.

Sustainable Concrete Solutions serves as an introduction to and an overview of the latest developments in sustainable concrete construction. It provides useful guidance, with further references, to students, researchers, academics and practitioners of all construction disciplines who are faced with the challenge of designing, specifying and constructing with concrete.

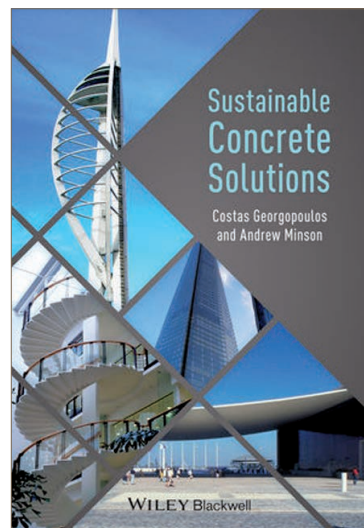

